Original Article

\title{
Coleoborers in Bambusa sp. in the Southern Amazon
}

\author{
Coleobrocas em Bambusa sp. na Amazonia Meridional
}

\author{
A. G. Oliveira ${ }^{a}$ (D) M. H. M. Silva ${ }^{b}$ (D) and J. Garlet ${ }^{* *}$ (D) \\ aUniversidade do Estado de Mato Grosso - UNEMAT, Faculdade de Ciências Biológicas e Agrárias, Curso de Engenharia Florestal, Campus II, \\ Alta Floresta, MT, Brasil \\ 'Instituto Federal de Mato Grosso, Alta Floresta, MT, Brasil \\ cUniversidade do Estado de Mato Grosso - UNEMAT, Faculdade de Ciências Biológicas e Agrárias, Programa de Pós-Graduação em \\ Biodiversidade e Agroecossistemas Amazônicos, Campus I, Alta Floresta, MT, Brasil
}

\begin{abstract}
Bamboo (Bambusa sp.) is a grass species with high potential for exploitation, however, this raw material is easily attacked by xylophagous agents such as Coleoptera. The objective of this study is thus to analyse the presence of wood-boring beetles associated with Bambusa sp. in Alta Floresta, Mato Grosso, Brazil. The study was carried out in a bamboo plantation, from August 2016 to July 2017. Two models of ethanolic traps were used, PET Santa Maria and ESALQ-84. Three families of wood-boring beetles were observed in this study: Bostrichidae, Cerambycidae and Curculionidae. 2,144 individuals were identified, belonging to 19 species, in four subfamilies and 11 tribes, and the species Xyleborus affinis was the most frequently collected. Thus, this study constitutes an important contribution to the knowledge of coleoborers associated with bamboo plantations, with the registration of the occurrence of species, as well as contributing to the knowledge of the entomofauna associated with species cultivated in the Southern Amazon.
\end{abstract}

Keywords: bamboo, coleoborers, ethanolic trap.

\begin{abstract}
Resumo
O bambu (Bambusa sp.) é uma espécie de gramínea com alto potencial de exploração de fibras, no entanto, essa matéria-prima é facilmente atacada por agentes xilófagos, como os coleópteros. O objetivo deste estudo foi analisar a presença de besouros associados a Bambusa sp. em Alta Floresta, Mato Grosso, Brasil. O estudo foi realizado em um plantio de bambu, no período de agosto de 2016 a julho de 2017. Foram utilizados dois modelos de armadilhas etanólicas, o PET Santa Maria e ESALQ-84. Três famílias de coleobrocas foram observadas neste estudo: Bostrichidae, Cerambycidae e Curculionidae. Foram identificados 2,144 indivíduos, pertencentes a 19 espécies, em quatro subfamílias e 11 tribos, e Xyleborus affinis foi a espécie com maior número de indivíduos coletados. Assim, este estudo constitui-se em uma importante contribuição para o conhecimento de coleobrocas associadas a plantios de bamboo, com o registro de ocorrência de espécies, bem como contribui para o conhecimento da entomofauna associada a espécies cultivadas na Amazônia Meridional.
\end{abstract}

Palavras-chave: bambu, coleobrocas, armadilha etanólica.

\section{Introduction}

Bamboo (Bambusa sp.) is an important species for fibre supply, given its mechanical resistance and versatility, as well as being adaptable to different environments and a natural renewable resource of low economic cost and of good quality, allowing construction and environmental care through environmental recovery and preservation (Da Silva, 2010). The species of native bamboos in Brazil has been increasingly used in the state of Mato Grosso and in the north-east (Sánchez et al., 2011). According to Matoski and Rocha (2006), the processing of wood, as well as of bamboo, goes through different industrial stages until its commercialization, and can be attacked by biodegrading agents mainly xylophagous insects, fungi and bacteria.
Among these biodegrading agents, Coleoptera stand out as the major cause of damage. The coleoborers or wood-boring beetles make galleries inside the plants, during their young phase and some species can grow symbiotic fungi, they can attack the wood, from the live tree to the drought in a decreasing humidity gradient. In addition to direct damage, this group has species that can transmit viruses (Oliveira et al., 1986).

The coleopterous are able to live in all types of habitats and to feed animals and plant material, and this order includes the main families of economic importance: Cerambycidae (wood saw); Curculionidae: Platypodinae and Scolytinae, (wood-boring beetles and leaf beetles)

*e-mail: julianagarlet@unemat.br

Received: May 9, 2020 - Accepted: February 12, 2021

This is an Open Access article distributed under the terms of the Creative Commons Attribution License, which permits unrestricted use, distribution, and reproduction in any medium, provided the original work is properly cited. 
Lyctidae, Bostrichidae and Anobiidae (spray beetles); Chrysomelidae (defoliating beetles) (Costa et al., 2014).

One of the biggest problems for bamboo is the damage caused by xylophagous agents, because its rich starch offers little natural resistance. The ideal would therefore be to subject it to treatment methods to avoid the action of these insects (Tiburtino et al., 2015). Espelho (2007) pointed out that most bamboo species are susceptible to attack by fungi and insects, such as the bamboo borer Dinoderus minutus Fabricius (1775) (Coleoptera: Bostrichidae: Dinoderinae), which destroys their stalk internally, and also by other xylophagous agents that feed on wood.

Considering the vast potential for using Bambusa sp., studies involving population surveys of insects in plantations are extremely important, especially with species of coleoborers, since this genus is susceptible to this group of insect pests. It is noteworthy that in research carried out on the subject, no studies were observed in this regard, there are only records of Bambusa susceptibility assessments to Dinoderus minutus. Thus, it is necessary to study and develop strategies to reduce the damage caused by insect pests, and to improve the Integrated Pest Management techniques associated with bamboo, ranging from population surveys. insects to decision-making and the implementation of appropriate control techniques.

The objective of this study was thus to analyze the occurrence of wood-boring beetles associated with Bambusa sp. in Alta Floresta, Mato Grosso, Brazil.

\section{Methods}

\subsection{Methodological procedures}

The survey was carried in an area whit Bambusa sp. of $800 \mathrm{~m}^{2}\left(09^{\circ} 56^{\prime}\right.$ 53.78” S; 56 06' 33.33” W) in Alta Floresta, Mato Grosso. Around the planting of Bambusa sp. there is a fragment of native forest and a pasture area. According to Alvares et al. (2013) and the Köppen Climate Classification, the climate of the region is type Am: hot and humid, with four months of drought, average temperatures above $26^{\circ} \mathrm{C}$ and annual precipitation of 2800 to $3100 \mathrm{~mm}$.

Two models of ethanolic trap were used for the capture of beetles: the PET Santa Maria (Murari et al., 2012) and ESALQ-84 (Berti Filho and Flechtmann, 1986), which were installed in 16 bamboo clumps, at a height of $1.5 \mathrm{~m}$ from the ground according to the recommendations for the two traps. Two models were used in order to sample the largest possible number of wood-boring beetles.

16 traps were installed, eight of each model, with the models interleaved. In order to avoid the edge effect, the traps were arranged in two transects in the central part of the plantation four meters from the edge. Since in the transects the traps were six meters apart, and the distance between the transects was four meters. Collections were carried out fortnightly, from August, 2016 until July, 2017. Families, subfamilies, and tribes were identified at Ceptam (Southern Amazonia Research and Technology Center), and the specimens identified as wood-boring beetles were sent to Dr Eli Nunes Marques of the Federal University of
Paraná and Dra Marcela Monné of the Federal University of Rio de Janeiro for identification at species level.

\subsection{Data analysis}

The indices evaluated in this study were calculated using the DivEs - Diversidade de Espécies - program available in version 4.0 (Rodrigues, 2015). The following measures, provided by the software, were used: Shannon-Wiener diversity index (H'), Simpson diversity index (S), Margalef diversity index $(\alpha)$, Pielou equability index $(J)$, Simpson equability index (ED), Simpson dominance index.

\section{Results}

Table 1 shows the species of wood-boring beetles analysed in the present study. A total of 2,144 individuals were sampled. 19 species of wood-boring beetles were collected, distributed in three families: Bostrichidae, Cerambycidae and Curculionidae, and in four subfamilies: Bostrichinae, Cerambycinae with five tribes (Achrysonini, Bothriospilini, Clytini, Lissonotini and Trachyderini), and Platypodinae (Platypodini: Platypodina), and Scolytinae with four tribes (Dryocoetini, Bothrosternini, Cryphalini and Xyleborini).

Curculionidae being the most representative family, followed by Cerambycidae and Bostrichidae. Regarding the subfamilies, Scolytinae was the most abundant and Platypodinae was the one with the lowest number of identified individuals. The Xyleborini tribe was the most abundant, mainly due to the high numbers of individuals of the genus Xyleborus.

Table 2 shows the diversity, equitability and dominance of the sampled environment. The diversity indices ranged from 0.67 to 5.4 , according to the particularities of each index used. Analysing the dominance of the collected species, it is observed that it was low (considering that the index varies from 0 to 1 , and the higher it is, the greater the probability that the individuals are of the same species), so there is no species dominance, which was also observed from the Pielou (J) and Simpson (ED) equitability indices close to 1 , indicating a situation where all species have a similar number of individuals.

\section{Discussion}

In the environment of Bambusa sp., wood-boring beetles were sampled in notable quantities, especially in relation to the family Curculionidae, which suggests that individuals of this family may present potential for damage. The largest number of individuals collected belongs to the genus Xyleborus (Curculionidae: Scolytinae). The genus Xyleborus is very common in tropical environments and has been reported in several surveys as causing damage to forest species in Brazil.

Souza et al. (2016) and Pinheiro (2018) evaluated the occurrence of wood-boring beetles in Mato Grosso, also found high representativeness values for the species $X$. affinis in relation to the total sampling. It is important to point out that $X$. affinis is a common xylomycetophagous 
Table 1. Number of individuals per wood-boring beetles species collected in Bambusa sp. area in Alta Floresta, Mato Grosso, Brazil.

Species $\quad \begin{gathered}\text { № of } \\ \text { individuals } \\ \text { collected }\end{gathered}$

\section{Bostrichidae: Bostrichinae}

Bostrichideo sp.

\section{Cerambycidae: Cerambycinae: Achrysonini}

Achryson surinamum (Linnaeus 1767)

\section{Cerambycidae: Cerambycinae: \\ Bothriospilini}

Chlorida festiva (Linnaeus 1758)

\section{Cerambycidae: Cerambycinae: Clytini \\ Megacyllene angulata (Fabricius 1775) \\ Neoclytus pusillus (Laporte and Gory 1836) \\ Cerambycidae: Cerambycinae: Lissonotini}

Lissonotus ephippiatus (Bates 1870)

8

\section{Cerambycidae: Cerambycinae:}

Trachyderini

Trachyderes succinctus (Linnaeus 1758)

\section{Curculionidae: Platypodinae: Platypodini}

Platypus linearis (Stephens 1830)

\section{Curculionidae: Platypodinae: Tesserocerini}

Tesserocerus sp.

\section{Curculionidae: Scolytinae: Bothrosternini}

Cnesinus dryografus (Schedl 1951)

\section{Curculionidae: Scolytinae: Dryocoetini}

Coccotrypes palmarum (Eggers 1933)

\section{Curculionidae: Scolytinae: Cryphalini}

Cryptocarenus sp.

Hypothenemus sp.

\section{Curculionidae: Scolytinae: Xyleborini}

Preminobius cavipenis (Eichhoff 1878)

Sampsonius dampfi (Schedl 1940)

Xyleborus affinis (Eichhoff 1868)

Xyleborus ferrugineus (Fabricius) 1801

Xyleborus retusus (Eggers 1928)

Xyleborus spinolosus (Blandford 1898)

species in almost all types of forest environments, has a wide distribution and is of great economic importance for commercial forest systems in several countries, especially due to the ability to promote direct and indirect damage such as logs and the staining of woody fabrics due to the presence of the symbiont fungus, which compromises the quality of the wood (Dorval et al., 2017).
Table 2. Indices of diversity, equitability and dominance for wood-boring beetles in the environment of Bambusa sp. area in Alta Floresta, Mato Grosso, Brazil.

\begin{tabular}{ll}
\hline \multicolumn{1}{c}{ Indices } & Values \\
\hline Diversity & \\
Shannon-Wiener $(\mathrm{H})$ & 2.44 \\
Simpson (S) & 0.67 \\
Margalef (a) & 5.40 \\
Equitability & \\
J (Pielou) & 0.91 \\
ED (Simpson) & 0.71 \\
Dominance & \\
Simpson & 0.33 \\
\hline
\end{tabular}

The genera Cryptocarenus sp. and Hypothenemus sp., belonging to the Cryphalini tribe, presented a large number of individuals collected. Similar to these results, Monteiro (2017) also studied an assembly of bark beetles in Eucalyptus and in native forest, in the Alta Floresta region and verified the occurrence of these genera with high values in relation to the total sample. Dorval, Peres Filho and Marques (2004), found in the evaluation of Scolytinae in Eucalyptus spp. plantations also in the state of Mato Grosso, a high representation of Cryptocarenus, Hypothenemus and Xyleborus, which these genera are easily found in the edaphoclimatic conditions of the biomes Cerrado and Amazon.

Furthermore, the authors Dorval, Peres Filho and Marques (2004), report that the large quantity of specimens of the genera Cryptocarenus sp. and Hypothenemus sp. are associated with their low specificity in choosing hosts, in addition to being very abundant throughout the year. These occurrences that species belonging to these two genera can present themselves as potential cause of damage in areas of bamboo, due to their eating habits and wide distribution.

In addition, Wood (1982) who points out that wood-boring beetles species of these group can be chosen as indicators of environments in imbalance or ecological disturbance, which may be related to the fact that in the bamboo planting facilities there are areas anthropized by agricultural activity.

The Cerambycidae family was the second most representative in the present study. Individuals in this family can cause damage to forest species during their larval period by boring trunks, branches and seeds, or during adulthood by sawing parts of plants (Paulino Neto, 2004; Morales-Silva et al., 2019). In this group, the most abundant species was Lissonotus ephippiatus e Trachyderes succinctus.

Barreto et al. (2013) carried out a study of the cerambycid diversity in forest environments in the northern region of Mato Grosso and identified 32 species; among these, they also found the occurrence of Trachyderes succinctus. In Brazil, Trachyderes succinctus has already been observed 
in different forest systems, frequent even in cultivated systems, having recently been reported to cause damage in Khaya ivorensis A. Chev. (Fujihara et al., 2020).

As shown in Table 2, the diversity rates verified in this study are considered high, demonstrating that in the environment of Bambusa sp. there is a wide diversity of wood-boring beetles species, with apparently uniform distribution among species without dominance. Cajaiba and Da Silva (2015) evaluated the diversity of beetles in forest fragments in the Amazon and also found a uniform pattern of species distribution with a Pielou $(\mathrm{J})$ index of 0.97 in the area furthest from the edge of the study area. Thus, more diverse and ecologically balanced forest environments tend to present fewer risks regarding the occurrence of population outbreaks with the potential for damage.

It is noteworthy that in research in the literature it was not possible to find works on survey of wood-boring beetles in general in Bambusa plantations in Brazil. Some punctual studies were observed with Dinoderus minutus, a pest species already known as in the work by Silveira et al. (2017) who evaluated the influence of environmental factors, and color and height of traps in the capture of this pest species. Dinoderus minutus has already been recorded in the Alta Floresta region in Eucalyptus urograndis plantations (Monteiro et al., 2016), but it was not found in the collections carried out in this study.

Thus, considering that plantations with Banbusa sp. are growing in Brazil, knowing the different species of insects associated with these plantations is essential, as the increase in the area planted with any plant species tends to increase the occurrence of entomological problems. So, it is important to highlight that monitoring the population fluctuation of wood-boring beetles in forest systems is of fundamental importance for understanding the interaction of these agents in the environment and for management strategies.

It is noteworthy, therefore, that this study constitutes an important contribution to the knowledge of wood-boring beetles associated with bamboo plantations, with the registration of the occurrence of species, as well as contributing to the knowledge of the entomofauna associated with species cultivated in the Southern Amazon.

\section{Conclusion}

It can be concluded that the largest numbers of insects found in the area of Bambusa sp. belong to the families Bostrichidae, Cerambycidae and Curculionidae, which are considered important wood borers. Nineteen species were observed within the three families of wood-boring beetles, and $X$. affinis presented the largest number of individuals collected.

\section{References}

ALVARES, C.A., STAPE, J.L., SENTELHAS, P.C., DE MORAES GONÇALVES, J.L. and SPAROVEK, G., 2013. Köppen's climate classification map for Brazil. Meteorologische Zeitschrift (Berlin), vol. 22, no. 6, pp. 711-728. http://dx.doi.org/10.1127/0941-2948/2013/0507.
BARRETO, M.R., MACHINER, R. and SMIDERLE, E.C., 2013. Cerambycinae (Coleoptera, Cerambycidae) em Mato Grosso, Brasil. Biota Neotropica, vol. 13, no. 1, pp. 331-335. http://dx.doi. org/10.1590/S1676-06032013000100032.

BERTI FILHO, E. and FLECHTMANN, C. A. H., 1986. A model of ethanol trap to collect Scolytidae and Platypodidae (Insecta, Coleoptera). Instituto de Pesquisas Florestais, no. 34, pp. 53-56.

CAJAIBA, R.L. and DA SILVA, W.B., 2015. Abundância e diversidade de Coleoptera (Arthropoda: Insecta) de solo em fragmentos de capoeira ao entorno da zona urbana do município de Uruará PA, Brasil. EntomoBrasilis, vol. 8, no. 1, pp. 30-37. http://dx.doi. org/10.12741/ebrasilis.v8i1.414.

COSTA, E.C., D’ÁVILA, M. and CANTARELLI, E.B., 2014. Entomologia florestal. 3. ed. Santa Maria: UFSM, 256 p.

DA SILVA, L.C., 2010. Criação de caruncho do bambu em laboratório em condições "in vitro" e avaliação de sua preferência alimentar por visão computacional. Campo Grande: Universidade Católica Dom Bosco, 30 p. Monografia de Graduação em Engenharia Agronômica.

DORVAL, A., PERES FILHO, O. and MARQUES, E.N., 2004. Levantamento de Scolytidae (Coleoptera) em plantações de Eucalyptus Spp. em Cuiabá, Estado de Mato Grosso. Ciência Florestal, vol. 14, no. 1, pp. 47-58. http://dx.doi.org/10.5902/198050981780.

DORVAL, A., PERES FILHO, O., MARQUES, E.N., SOUZA, M.D. and JORGE, V.C., 2017. Sazonalidade de Xyleborus ferrugineus e Xyleborus affinis (Curculionidae: Scolytinae) em savana arbórea fechada. Espacios, vol. 38, no. 28, pp. 28-38.

ESPELHO, J.C.C., 2007. Tratamento químico de colmos de bambu pelo método de boucherie modificado. Campinas: Universidade Estadual de Campinas, 113 p. Dissertação de Mestrado em Engenharia Agrícola.

FUJIHARA, R.T., VIANIA, R.A.G. and SAVARIS, M., 2020. First record of Trachyderes succinctus succinctus (Linnaeus, 1758) (Coleoptera: Cerambycidae) in Khaya ivorensis A. Chev. (Meliaceae) in Brazil. Brazilian Journal of Biology = Revista Brasileira de Biologia, vol. 81, no. 1, pp. 220-222. https://doi.org/10.1590/1519-6984.226537.

MATOSKI, S.L.S. and ROCHA, M.P., 2006. Influência do fotoperíodo no ataque de Dinoderus minutus Fabricius (Coleoptera: Bostrichidae) em lâminas torneadas de espécies tropicais. Floresta, vol. 36, no. 3, pp. 385-396. http://dx.doi.org/10.5380/rf.v36i3.7518.

MONTEIRO, M., 2017. Assembléia de escolitíneos (Curculionidae: Scolytinae) em ambientes florestais na Amazônia meridional em Alta Floresta, Mato Grosso. Alta Floresta: Universidade do Estado de Mato Grosso, 81 p. Dissertação de Mestrado em Biodiversidade e Agroecossistemas Amazônicos.

MONTEIRO, M., GARLET, J., CARVALHO, C.C. and MARQUES, E.N., 2016. Occurrence of Dinoderus minutus (Fabricius, 1775) in the Northern State of Mato Grosso, Brazil. Entomological News, vol. 126, no. 3, pp. 237-240. http://dx.doi.org/10.3157/021.126.0310.

MORALES-SILVA, T., MAIA, L.F., MARTINS, A.L. and MODESTOZAMPIERON, S.L., 2019. Herbivore, parasitoid and hyperparasitoid insects associated with fruits and seeds of Enterolobium contortisiliquum (Vell.) Morong (Fabaceae). Brazilian Journal of Biology = Revista Brasileira de Biologia, vol. 79, no. 3, pp. 369-376. http://dx.doi.org/10.1590/1519-6984.170105. PMid:30231136.

MURARI, A.B., COSTA, E.C., BOSCARDIN, J. and GARLET, J., 2012. Modelo de armadilha etanólica de interceptação de vôo para captura de escolitídeos (Curculionidae: scolytinae). Pesquisa Florestal Brasileira, vol. 32, no. 69, pp. 115-117. http://dx.doi. org/10.4336/2012.pfb.32.69.115.

OLIVEIRA, A.M.F., LELIS, A.T., LEPAGE, E.S., LOPEZ, G.A.C., OLIVEIRA, L.C.S., CAÑEDO, M.D. and MILANO, S., 1986. Agentes destruidores 
de madeira. In: E.S. LEPAGE, ed. Manual de preservação de madeiras. São Paulo: IPT, pp. 99-278.

PAULINO NETO, H.F., 2004. Lenhadores da natureza. Ciência Hoje, vol. 35, no. 208, pp. 67-69.

PINHEIRO, A., 2018. Comportamento de voo e Flutuação Populacional de Coleópteros em uma área de Savana no Mato Grosso. Cuiabá: Universidade Federal de Mato Grosso, 40 p. Dissertação de Mestrado em Ciências Florestais e Ambientais.

RODRIGUES, W.C., 2015. DivEs - Diversidade de Espécies v3.0 - Guia do Usuário. Rio de Janeiro: Entomologistas do Brasil, 33 p.

SÁNCHEZ, S.E.M., AYRES, R.J. and MÉNDEZ, E.C., 2011. Ocorrência de Dinoderus Stephens, 1830 (Coleoptera: Bostrichidae) e Cornitermes Wasmann, 1897 (Isoptera: Termitidae), em touceiras de bambus no município de Ilhéus (Bahia), Brasil. Entomotrópica, vol. 26, no. 2, pp. 99-105.
SILVEIRA, E.S., SILVA, R.M., ROEL, A.R. and CEREDA, M.P., 2017. Influência de fatores ambientais, cor e altura de armadilhas na captura do caruncho do bambu. Revista de Agricultura Neotropical, vol. 4, no. 4, pp. 8-14. http://dx.doi.org/10.32404/ rean.v4i4.1672.

SOUZA, M.D., SOUSA, N.J., PERES-FILHO, O., DORVAL, A., MARQUES, E.N. and JORGE, V.C., 2016. Ocorrência de Scolytinae com armadilhas etanólica contendo diferentes concentrações de etanol. Espacios, vol. 37, no. 16, pp. 27.

TIBURTINO, R.F., PAES, J.B., VIDAURRE, G.B., BROCCO, V.F. and ARANTES, M.D.C., 2015. Resistência de duas espécies de bambu tratadas com ccb contra cupins e coleópteros xilófagos. Ciência Florestal, vol. 25, no. 2, pp. 425-435. http://dx.doi. org/10.5902/1980509818462.

WOOD, S.L., 1982. The bark and ambrosia beetles of North and Central America (Coleoptera: Scolytidae): a taxonomic monograph. Great Basin Naturalist Memoirs. USA: Brigham Young University, 1359 p. 